та управління національним господарством (051 - Економіка). Харківський національний автомобільно-дорожній університет Міністерства освіти і науки України, Харків, 2020. - Український державний університет залізничного транспорту Міністерства освіти і науки України, Харків, 2020. 525 с.

DOI https://doi.org/10.30525/978-9934-26-046-9-54

\title{
ДОСЛІДЖЕННЯ ДИНАМІЧНОЇ НАВАНТАЖЕНОСТІ ТА МІЦНОСТІ НЕСУЧОЇ КОНСТРУКЦІЇ КРИТОГО ВАГОНА З ПРУЖНО-ФРИКЦЙНОЮ ХРЕБТОВОЮ БАЛКОЮ
}

\author{
Фомін О. В. \\ доктор технічних наук, професор, \\ професор кафедри вагонів та вагонного господарства \\ Державний університет інфраструктури та технологій \\ м. Київ, Україна \\ Ловська А. О. \\ кандидат технічних наук, доцент, \\ доцент кафедри інженерії вагонів та якості продукиії \\ Украйнський державний університет залізничного транспорту \\ м. Харків, Україна
}

Рибін А. В.

старший викладач кафедри інженерї вагонів та якості продукиії Украӥнський державний університет залізничного транспорту м. Харків, Україна

Перспективи розвитку транспортної інфраструктури викликають необхідність підвищення ефективності експлуатації залізничного транспорту, як іiі провідної галузі. При цьому особлива увага повинна приділятися технічній забезпеченості залізничного парку.

Для перевезення вантажів, які потребують захисту від атмосферних опадів використовуються криті вагони. Відомо, що найбільш пошкоджуваним елементом несучих конструкцій критих вагонів $\epsilon$ рама. Здебільшого ії пошкодження обумовлені дією значних динамічних навантажень, що виникають в експлуатації. Циклічність дії цих 
навантажень зменшує втомну міцність несучих конструкцій вагонів. Така обставина викликає необхідність проведення позапланових видів ремонту або виключення вагонів з інвентарного парку.

Тому важливим є впровадження в експлуатацію інноваційного рухомого складу для утримання лідерських позицій залізничної галузі на ринку транспортних послуг. При проектуванні такого рухомого складу необхідно використання нових нетривіальних рішень, спрямованих на підвищення втомної міцності, а відповідно і проектного строку служби [1-3]. Це зумовлює необхідність проведення відповідних досліджень та створення напрацювань в даному напряму.

Для зменшення динамічної навантаженості несучої конструкції критого вагона та підвищення втомної міцності при експлуатаційних режимах пропонується впровадження в нього пружних елементів. Розміщення пружних елементів передбачається у хребтовій балці за їі довжиною між задніми упорами автозчепів. Для цього пропонується використання замість типового профілю хребтової балки П-подібного.

Зменшення динамічної навантаженості хребтової балки при цьому досягається за рахунок опору сил сухого тертя між вертикальними полками П-подібного профілю, а також вертикальними частинами горизонтального листа при коливаннях підскакування вагона.

Дослідження проведені стосовно критого вагона моделі 11-217. Для визначення динамічної навантаженості несучої конструкції критого вагона з урахуванням запропонованих заходів проведено математичне моделювання. Дослідження проведені в площині XZ. Вагон при цьому розглядається як система 3 трьох твердих тіл - несучої конструкції та двох візків моделі 18-100 з ресорними комплектами, які мають жорсткість та коефіцієнт відносного тертя.

Враховано, що на систему накладені такі зв'язки:

- переміщення кузова та візків вагона уздовж осі колії однакові.

- колісні пари рухаються без проковзування.

- через відсутність пружних елементів в буксовому підвішуванні підстрибування візків визначаються підстрибуванням колісних пар.

Враховано, що вагон рухається у порожньому стані стиковою нерівністю. Вхідними параметрами моделі $є$ технічні характеристики несучої конструкції критого вагона, ресорного підвішування, а також збурюючої дії. Розв'язок диференціальних рівнянь руху здійснений в програмному комплексі MathCad . При цьому початкові переміщення та швидкості покладені рівними нулю. 
Максимальне вертикальне прискорення несучої конструкції критого вагона у порожньому стані склало близько $1,57 \mathrm{~m} / \mathrm{c}^{2}(0,16 \mathrm{~g})$, а візків - близько $8,3 \mathrm{~m} / \mathrm{c}^{2}(0,8 \mathrm{~g})$. 3 урахуванням запропонованого $\mathrm{pi}$ шення стає можливим знизити вертикальні прискорення, які діють на несучу конструкцію вагона майже на $20 \%$. Хід вагона оцінюється як «відмінний» $[4 ; 5]$.

Для визначення основних показників міцності несучої конструкції критого вагона 3 пружними елементами в хребтовій балці проведено розрахунок за методом скінчених елементів в програмному комплексу SolidWorks Simulation (CosmosWorks).

Максимальні еквівалентні напруження при цьому зафіксовані у зоні взаємодії шворневої балки 3 хребтовою та склали 137,4 МПа. Максимальні переміщення виникають у середній частині хребтової балки та дорівнюють 1,2 мм. Отже міцність несучої конструкції критого вагона забезпечується $[4 ; 5]$.

Визначено проектний строк служби несучої конструкції критого вагона 3 урахуванням запропонованих заходів щодо удосконалення. Проектний строк служби складає близько 40 років, що вище майже на $20 \%$ за строк служби вагону-прототипу.

\section{Висновки та пропозиції.}

1. Запропоновано заходи щодо зменшення динамічної навантаженості критого вагона шляхом впровадження в хребтову балку, як основного несучого елемента рами, пружних елементів. Це сприяє перетворенню динамічних навантажень, які діють на несучу конструкцію у роботу сил сухого тертя між складовими хребтової балки.

2. Проведено математичне моделювання динамічної навантаженості критого вагона з урахуванням запропонованих заходів. Максимальне вертикальне прискорення несучої конструкції критого вагона у порожньому стані складає близько $1,57 \mathrm{~m} / \mathrm{c}^{2}(0,16 \mathrm{~g})$, а візків - близько $8,3 \mathrm{~m} / \mathrm{c}^{2}(0,8 \mathrm{~g})$. 3 урахуванням запропонованого рішення стає можливим знизити вертикальні прискорення, які діють на несучу конструкцію вагона майже на $20 \%$.

3. Визначено основні показники міцності несучої конструкції критого вагона з урахуванням запропонованих заходів. Максимальні еквівалентні напруження при цьому виникають у зоні взаємодії шворневої балки з хребтовою та складають 137,4 МПа. Максимальні переміщення виникають у середній частині хребтової балки та дорівнюють 1,2 мм. Отже міцність несучої конструкції критого вагона забезпечується. 
Проектний строк служби запропонованої несучої конструкції критого вагона складає близько 40 років. Отримане значення проектного строку служби вище майже на $20 \%$ за строк служби вагонупрототипу.

Проведені дослідження сприятимуть підвищенню ефективності експлуатації залізничного транспорту.

\section{Література:}

1. Fomin Oleksij, Lovska Alyona, Radkevych Valentyna, Horban Anatoliy, Skliarenko Inna Gurenkova Olga. The dynamic loading analysis of containers placed on a flat wagon during shunting collisions. ARPN Journal of Engineering and Applied Sciences. 2019. Vol. 14, No. 21. P. 3747-3752.

2. Fomin O., Lovska A. Improvements in passenger car body for higher stability of train ferry. Engineering Science and Technology an International Journal. 2020. Vol. 23, Issue 6, P. 1455-1465. https://doi.org/10.1016/j.jestch.2020.08.010

3. Fomin O., Lovska A., Píštěk V., Kučera P. Dynamic load effect on the transportation safety of tank containers as part of combined trains on railway ferries. VIBROENGINEERING PROCEDIA. 2019. Vol. 29, P. 124-129.

4. ДСТУ 7598:2014. Вагони вантажні. Загальні вимоги до розрахунків та проектування нових і модернізованих вагонів колії 1520 мм (несамохідних). Київ, 2015. 162 с.

5. ГОСТ 33211-2014. Вагоны грузовые. Требования к прочности и динамическим качествам. Москва, 2016. 54 с. 